\title{
21. PALEOGENE SHALLOW-WATER LARGER FORAMINIFERS FROM HOLES 714A AND 715A, LEG 115, INDIAN OCEAN1
}

\author{
Alda Nicora ${ }^{2}$ and Isabella Premoli Silva ${ }^{2}$
}

\begin{abstract}
Shallow-water larger foraminifers have been recovered at two drill sites on the eastern Maldive Ridge. Despite the poor recovery in Hole 715A, a rather diversified larger benthic foraminifer assemblage allowed us to date the initiation of a carbonate platform, resting on volcanic basement, as late early Eocene. Several age-diagnostic species belonging to the genera Alveolina, Nummulites, Orbitolites, and Discocyclina have been identified. The assemblages may be attributable to the upper part of the Nummulites burdigalensis cantabricus Zone and/or to the lower part of the Nummulites campesinus Zone and to the Alveolina dainellii (upper part) and/or to the $A$. violae (lower part) zones. The carbonate platform had a very short life (a few hundred thousand years) and rapidly sank below the euphotic zone, as testified by the occurrence of several species of planktonic foraminifers associated with redeposited reef-derived skeletal debris, especially discocyclinids, in the upper part of the sequence. Among the planktonic foraminifers, the presence of Planorotalites palmeri, which has a range confined to the lower portion of the late early Eocene Zone P9, implies that the platform was drowned before the end of the early Eocene.

At Hole 714A, the occurrence of several shallow-water foraminifer genera, such as Nummulites ( $N$. fabianii gr.), Discocyclina, Fabiania, Heterostegina, and Operculina (O. gomezi), in pebbles derived from turbidite beds interbedded within late Oligocene pelagic sediments, allows us to suggest that a carbonate platform, possibly reduced in size, was still growing in the Maldive Ridge area after the late early Eocene time. The erosional event, responsible for the redeposition of middle to late Eocene reef-derived skeletal debris, is apparently coeval with the global sea-level fall recorded in late Oligocene Zone P22.
\end{abstract}

\section{INTRODUCTION}

Paleogene shallow-water larger benthic foraminifers were recovered at Holes 714A and 715A during Ocean Drilling Program (ODP) Leg 115 in the Indian Ocean, located on the eastern margin of the Maldive Ridge (Fig. 1).

Shallow-water skeletal debris of late Paleocene to early Eocene age was previously found in the Indian Ocean at DSDP Hole 219A from 240 to 411 mbsf, drilled on the Laccadive-Chagos Ridge in $1764 \mathrm{~m}$ water depth and located about $4^{\circ}$ latitude north of the Maldive Ridge sites discussed here (Whitmarsh, Weser, Ross, et al., 1974). Mamgain et al. (in Whitmarsh et al., 1974, p. 44) identified few representatives of the genera Operculina and Discocyclina associated with some bryozoans, pelecypods, and red algae. These shallow-water assemblages were never described nor illustrated after the publication of the Initial Reports.

\section{Hole 715A}

Hole $715 \mathrm{~A}$ was drilled on the eastern margin of the Maldive Ridge at $05^{\circ} 04.89^{\prime} \mathrm{N}$ and $73^{\circ} 49.88^{\prime} \mathrm{E}$ in a water depth of $2262.3 \mathrm{~m}$ with a total penetration of $287.8 \mathrm{~m}$ (Backman, Duncan, et al., 1988). Hole 715A penetrated basalt at $211.3 \mathrm{mbsf}$ and continued $76.6 \mathrm{~m}$ further into basement. Above the basalt was $100 \mathrm{~m}$ of early Eocene shallow-water limestones. Pelagic nannofossil oozes of Pleistocene to Miocene age lie above the limestone unit. A total of 31 cores were taken, 12 of which (Cores 115-715A-12R to -23R) belong to the shallow-water limestone unit, with only $7.7 \%$ recovery.

The shallow-water limestones, identified as Unit III (Cores 115-715A-12R to -23R), consist of wackestone (Core 115-715A-

\footnotetext{
${ }^{1}$ Duncan, R. A., Backman, J., Peterson, L. C., et al., 1990. Proc. ODP, Sci. Results, 115: College Station, TX (Ocean Drilling Program).

2 Dipartimento di Scienze della Terra, Università di Milano, via Mangiagalli 34, Milano 20133, Italy.
}

12R), packstones (Cores 115-715A-13R to $-15 R$ and -23R), packstones and grainstones (Cores 115-715A-16R to -21R), and grainstones (Core 115-715A-22R). The recovered material consists of numerous chunks, $1-20 \mathrm{~cm}$ in diameter, of very consolidated limestone. Consequently, the study of the fossil content was carried out on thin sections.

Typical shallow-water reefal assemblages, rich in age-diagnostic larger benthic foraminifers, predominate in most of the cores. In the upper part of the interval, they are associated with age-diagnostic planktonic foraminifers.

The faunal distribution is shown on Table 1 and the main bioevents summarized on Figure 2.

\section{Fossil Content}

The following four major assemblages may be distinguished from top to bottom:

1. In the interval from Core $115-715 \mathrm{~A}-12 \mathrm{R}-1,14-17 \mathrm{~cm}$, to Core $115-715 \mathrm{~A}-14 \mathrm{R}-1,33-35 \mathrm{~cm}$, the assemblages are characterized by the occurrence of planktonic foraminifers, the abundance of which decreases downhole. Planktonic foraminifers are limited to a few specimens in the lowermost sample. Conversely, larger foraminifers associated with melobesian algae and rare bryozoans become progressively more abundant downhole. The most frequent planktonic species identified in this interval are Planorotalites palmeri, Planorotalites pseudoscitulus, "Globigerinatheka" senni, Subbotina pseudoeocaena, the Acarinina pentacamerata group, Acarinina rohri group, Acarinina pseudotopilensis, and Pseudohastigerina wilcoxensis associated with rare Morozovella aragonensis, Morozovella crassata, and Chiloguembelina sp. Larger foraminifer assemblages are dominated by strongly fragmented discocyclinids associated with small numbers of better preserved nummulitids. Alveolinids are very rare and confined to the lowermost samples of this interval. The following species and genera were identified: Nummulites pratti, Nummulites cf. caupennensis, Nummulites sp., Discocyclina sella, Discocyclina douvillei, Asterocyclina spp., Operculina sp., Alveolina 
A
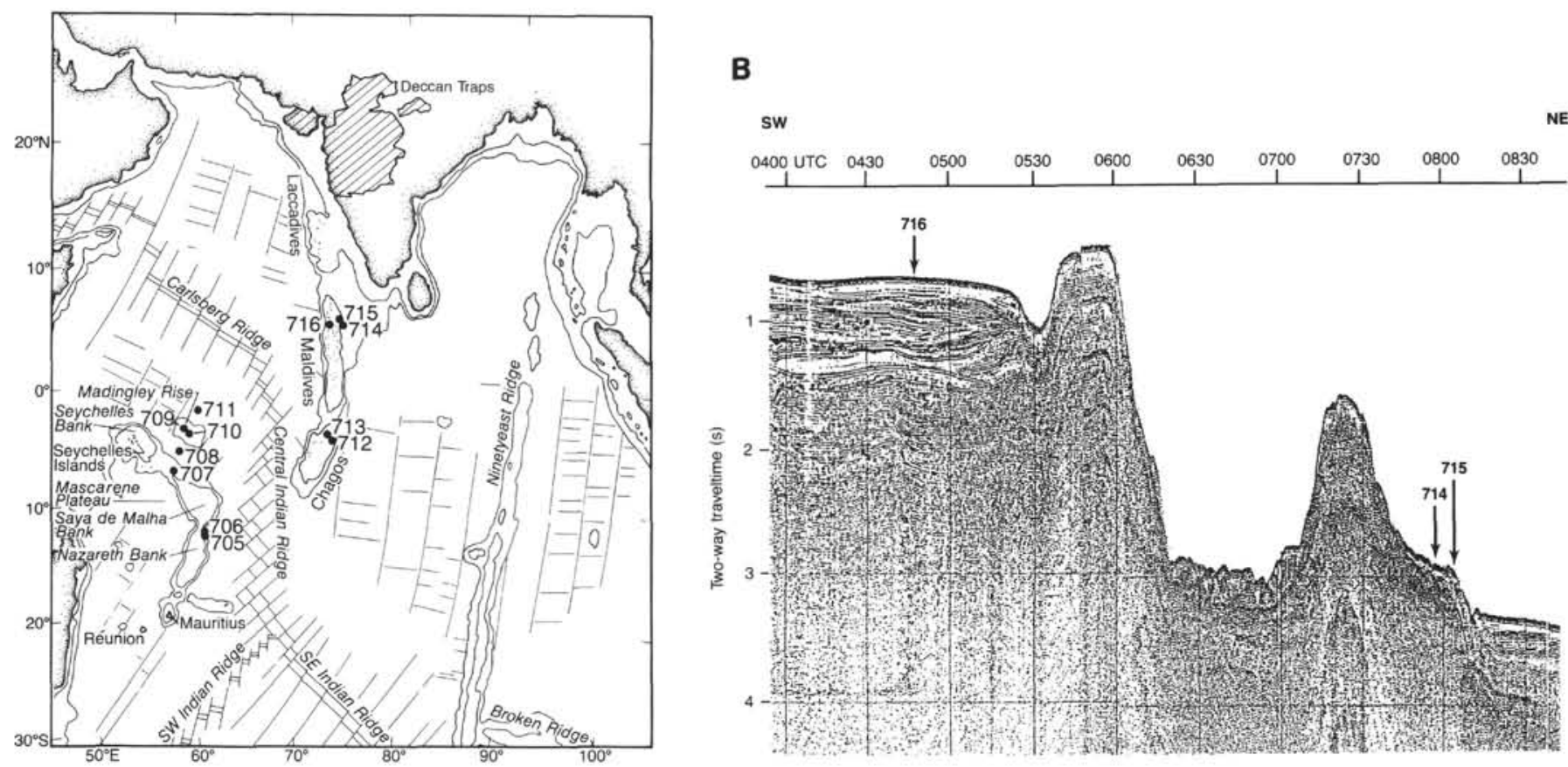

Figure 1. Location of Sites 714 and 715 in the Indian Ocean. A. Bathymetric map. B. Seismic profile (after Backman, Duncan, et al., 1988).

canavarii group, and small rotaliids. Miliolids and agglutinated foraminifers are rare.

2. From Core $115-715 \mathrm{~A}-14 \mathrm{R}-1,40-43 \mathrm{~cm}$, to Core $115-715 \mathrm{~A}-$ $14 \mathrm{R}-\mathrm{CC}$, the assemblages are characterized by the occurrence of very abundant granulated (with pillars) Nummulites belonging to the $N$. burdigalensis group, several Alveolina species $(A$. canavarii group, $A$. dainellii to $A$. palermitana transitional forms), and discocyclinids (occasionally fragmented) associated with Orbitolites $(O$. sp. cf. $O$. douvillei) and Operculina. Rotalia sp., Linderina?, and miliolids are also present. The assemblages also comprise several dasycladacean and melobesian algae, rare gastropods, and corals.

3. From Core 115-715A-15R-1, 41-44 cm, to Core 115-715A19R-1, 2-5 cm, the assemblages are characterized by several $A l$ veolina ( $A$. canavarii group, $A$. cf. dainellii, transitional forms from $A$. dainellii to $A$. palermitana, individuals of the $A$. aragonensis group, and $A$. fornasinii), granulated Nummulites ( $N$. burdigalensis group and rare specimens of the $N$. partschi group), Orbitolites, and rare discocyclinids, associated with melobesian algae (e.g., Distichoplax), Ethelia, dasycladaceans, coral fragments, hydrozoans, gastropods, and echinoids. Miliolids and rotaliids are frequent.

4. From Core $115-715 \mathrm{~A}-19 \mathrm{R}-1,10-12 \mathrm{~cm}$, to Core $115-715 \mathrm{~A}-$ $23 \mathrm{R}-1,34-36 \mathrm{~cm}$, the assemblages are characterized by very abundant small benthic foraminifers (miliolids, rotaliids, rare agglutinated forms) associated with much rarer larger foraminifers, frequent melobesian algae (e.g., Distichoplax), rare dasycladaceans, and Halimeda. Larger foraminifers belong to $\mathrm{Al}$ veolina ( $A$. cf. dainellii, $A$. dainellii/A. palermitana transitional forms, Alveolina sp. aff. A. palermitana, the $A$. aragonensis group, and $A$. fornasinii), the Nummulites burdigalensis group $(N$. burdigalensis s. str. and forms close to $N$. burdigalensis cantabricus $/ N$. campesinus), Orbitolites cf. O. douvillei, and Orbitolites sp. A few discocyclinids are present in the upper part.

\section{Bio- and Chronostratigraphy}

Larger foraminifers are known to have evolved rather rapidly through time. Among them the alveolinids and nummulitids were revealed to be the most useful groups biostratigraphically for constructing zonal schemes for the Paleocene to Eocene interval, especially for the Tethys province (Hottinger, 1960; Schaub, 1951, 1981). Moreover, these zonal schemes recently have been correlated to the calcareous nannofossil zonation (Schaub, 1981) (Fig. 3).

The shallow-water assemblages from the Maldive Ridge contain several specimens attributable to the genera Alveolina, Nummulites, and, more rarely, Orbitolites. Although the larger foraminifers are abundant throughout the studied interval, only a few could be specifically identified. The recovery of a few chunks of limestone in Hole 715A prevented us from cutting oriented sections of these larger foraminifers, on which reliable identifications might be based. Some thin sections, however, yielded a few cuts, more or less properly oriented, that allowed identification at a specific level. All the identified species have been described from the Tethyan province; thus, the Tethyan zonal schemes could be applied, allowing correlation between Indian Ocean and Tethyan faunas (Hottinger, 1960; Lehmann, 1961; Schaub, 1981). The age of the sequence could be established fairly accurately for the combined occurrence of the few age-diagnostic species of both alveolinids and nummulitids.

The most important occurrences are as follows (from bottom to top) (Fig. 2):

1. The first occurrence (FO) of representatives of the $A l$ veolina aragonensis group and A. fornasinii in Sample 115715A-23R-1, 34-36 cm;

2. The FO of representatives of the Nummulites burdigalensis group in Sample 115-715A-22R-CC; 
Table 1. Distribution of early late Eocene fossil content in Hole 715A.

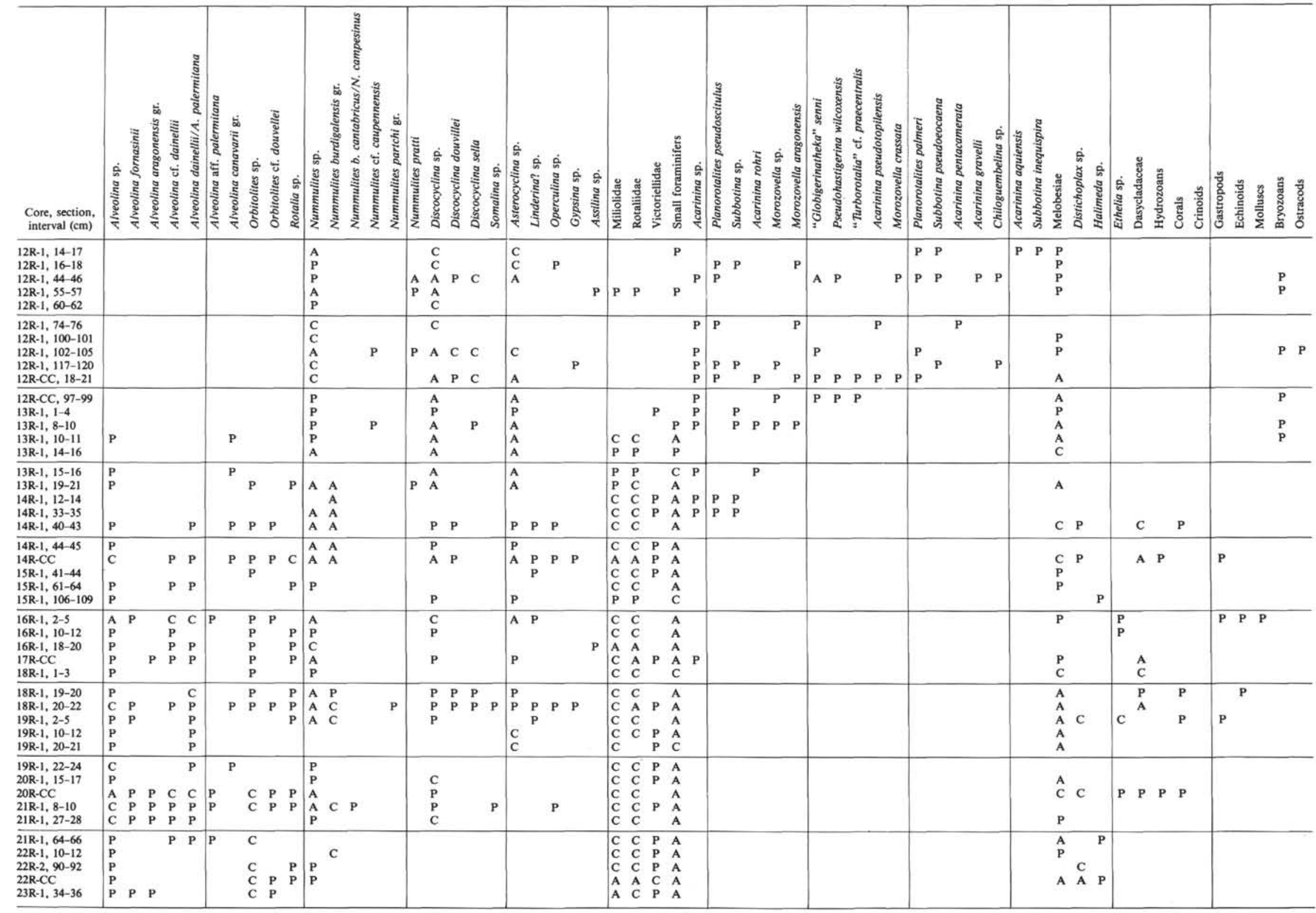




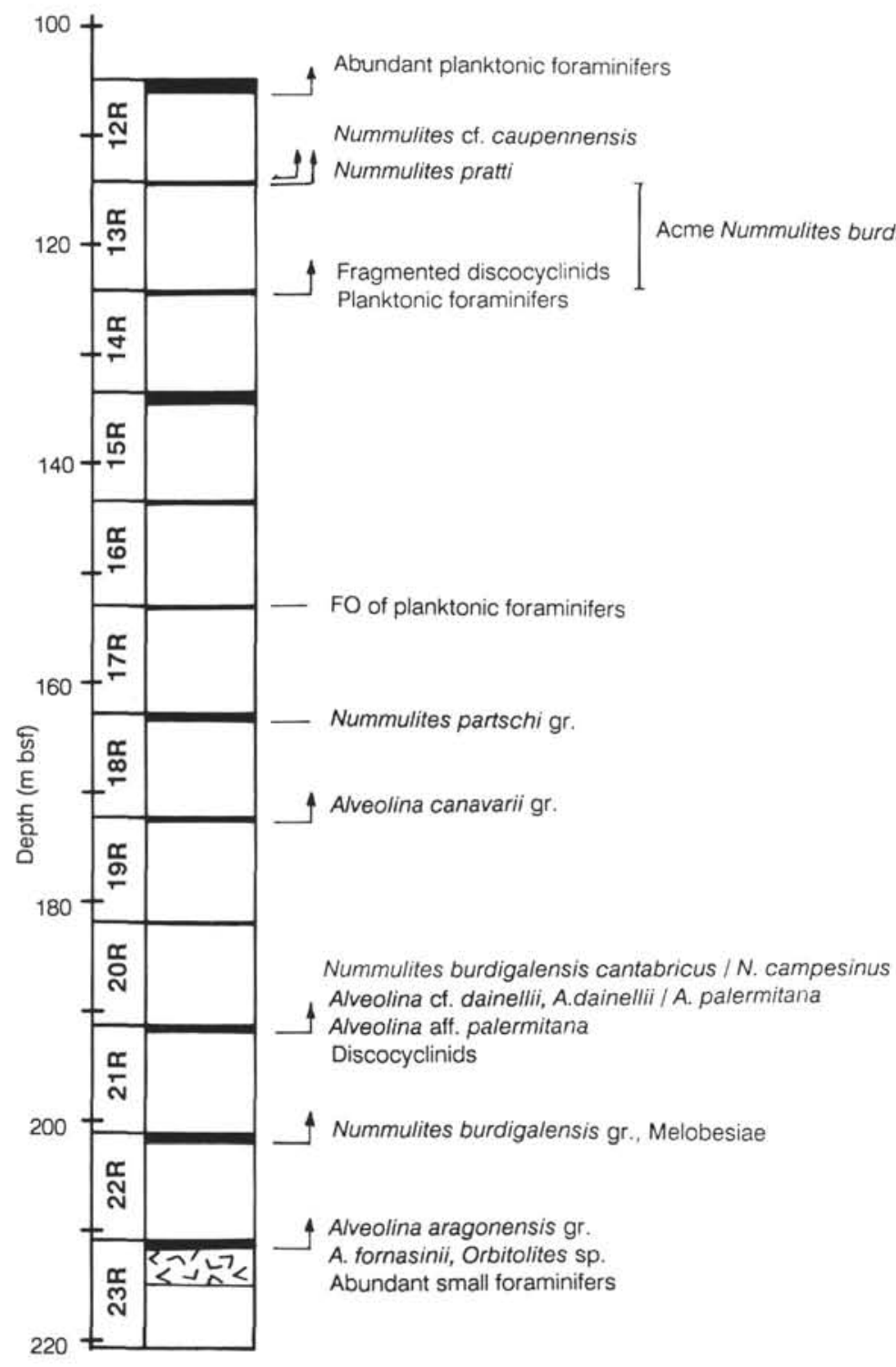

Figure 2. Succession of main bioevents recorded in Hole 715A above basement (late early Eocene). Note the very poor recovery (plain black).

3. The FO of Alveolina cf. dainellii and transitional forms to $A$. palermitana and Alveolina sp. aff. A. palermitana in Sample 115-715A-21R-1, 64-66 cm;

4. The FO of forms close to Nummulites burdigalensis cantabricus/N. campesinus in Sample 115-715A-21R-1, 8-10 cm;

5. The FO of representatives of the Alveolina canavarii group in Sample 115-715A-19R-1, 22-24 cm;

6. The FO of representatives of the Nummulites partschi group in Sample 115-715A-18R-1, 20-22 cm;

7. The FO of planktonic foraminifers in Sample 115-715A17R-CC;

8. The acme of representatives of the Nummulites burdigalensis group from Sample 115-715A-14R-CC to Sample 115715A-13R-1, 19-21 cm;

9. The FO of Nummulites pratti in Sample 115-715A-13R-1, $19-21 \mathrm{~cm}$;

10. The FO of Nummulites cf. caupennensis in Sample 115715A-13R-1, 8-10 cm; and

11. The FO of Planorotalites palmeri in Sample 115-715A12R-CC, $18-21 \mathrm{~cm}$.
Based on the occurrences listed above, the following age determinations are possible.

The presence of Alveolina $\mathrm{cf}$. dainellii, several transitional forms from $A$. dainellii to $A$. palermitana, and a few $A$. aff. $p a-$ lermitana along with other specimens belonging to the $A$. aragonensis group and to $A$. fornasinii suggests that these assemblages may be from the top of the Alveolina dainellii Zone or the base of the Alveolina violae Zone (Hottinger, 1960). The presence of representatives of the Alveolina canavarii group higher in the sequence is consistent with such an attribution.

The nummulitid assemblage throughout the sequence studied is characterized by the continuous presence of representatives of the Nummulites burdigalensis group, which show an acme from Core $115-715 \mathrm{~A}-13 \mathrm{R}-1,19-21 \mathrm{~cm}$, to Core $115-715 \mathrm{~A}$ 14R-CC (Figs. 4 and 5). Beside typical $N$. burdigalensis, in the lower part of the sequence a specimen (Form B) close to N. burdigalensis cantabricus and/or $N$. campesinus was identified in Sample 115-715A-21R-1, 8-10 cm. Higher in the sequence, a representative of the $N$. partschi group was recognized, followed in the upper part by the appearance of $N$. pratti along with $N$. 


\begin{tabular}{|c|c|c|c|c|c|c|c|c|c|}
\hline & & & & & & $\mathrm{BIO}$ & NES & & \\
\hline SERI & & & GES & & Nummulites & & Assilina & Alveolina & Calcareous \\
\hline & & & & N.brongniarti gr. & N.perforatus gr. & Others & & & nannofossils \\
\hline OLIGOC & CENE & & wer & & & fichteli & & & Er.subdistichă \\
\hline & upper & Pria & onian & & & fabianii & & (Neoalveolina) & $\begin{array}{l}\text { I.pseudooradians } \\
\text { l.recurvus }\end{array}$ \\
\hline & & & itzian & brongniarti & perforatus & ptukhiani & & elongata & Ch.oamaruensis \\
\hline & middle & & upper & herbi & aturicus & bullatus & gigantea & & \\
\hline w & & 들 & middle 2 & sordensis & crassus & & planospira & prorrecta & Disc.tani nodifer \\
\hline w & & ฐัँ & middle 1 & gratus & beneharnensis & & spira spira & munieri & \\
\hline $\begin{array}{l}u \\
\text { O }\end{array}$ & & $\begin{array}{c}3 \\
\text { lower }\end{array}$ & $\begin{array}{r}\text { lower } 2 \\
=\text { basal }\end{array}$ & laevigatus & obesus gallensis & & spira abrardi & stipes & Chiphr.alatus \\
\hline & & & upper & mantredi & campesinus & formosus & maior & violae & Disc.sublodoensis \\
\hline & & $\frac{\frac{10}{30}}{7}$ & middle & praelaevigatus & burd.cantabricus & nitidus & laxispira & dainellii & Disc.lodoensis \\
\hline & lower & 0 & lower 2 & olanulatus & burdigalensis & aff/axus & olana & oblonga & \\
\hline$=(1)=$ & & lower & $=$ basal & & burdigalensis & & planld & Ovioniga & Marth.tribrachiatus \\
\hline upper & & & upper & involutus & & laxus & adrianensis & trempina & \\
\hline - (1) & (2) & $\frac{5}{\pi}$ & middle 2 & exilis & pernotus & globulus & leymeriei & corbarica & Disc.binodosus \\
\hline & & 훙 & middle 1 & robustiformis & & carcasonensis & aff.arenensis & moussoulensis & \\
\hline & & & lower 2 & fraasi & solitarius & minervensis & arenensis & ellipsoidalis & Marth.contortus \\
\hline$z$ & {$[$ (2) } & & lower 1 & "Idast & & deserti & prisca & cucumiformis & \\
\hline ü middle & upper & 둬 & upper & & & & yvettae & levis & Disc.multiradiatus \\
\hline $\begin{array}{ll}0 & (1) \\
& \\
& \end{array}$ & (2) & 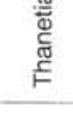 & lower & & & & & primaeva & $\begin{array}{c}\text { Hel.riedeli } \\
\text { Disc.gemmeus } \\
\text { Hel.kleinpelli } \\
\text { Fasc.tympaniformis }\end{array}$ \\
\hline a & lower & & nian & & & & & & $\begin{array}{l}\text { Ell.macellus } \\
\text { Chiasm.danicus } \\
\text { Crucipl.tenuis } \\
\text { Markal.inversus }\end{array}$ \\
\hline
\end{tabular}

Figure 3. Correlation between Paleogene larger foraminifer and calcareous nannofossil biozones, plotted vs. stages (after Schaub, 1981, modified). (1). Position of Paleocene/Eocene boundary according to Hottinger and Schaub (1960). (2). Position of Paleocene/Eocene boundary according to Special Meeting Soc. Géol. France, Nov. 18, 1974 (Boll. Soc. Géol. France, 1975) (fide Schaub, 1981).


Figure 4. Sample 115-715A-12R-1, 102-105 cm. A. Nummulites $\mathrm{cf}$. caupennensis, Form A, slightly oblique equatorial section $(\times 12)$. B. Nummulites pratti, Form A, axial section $(\times 13)$. 


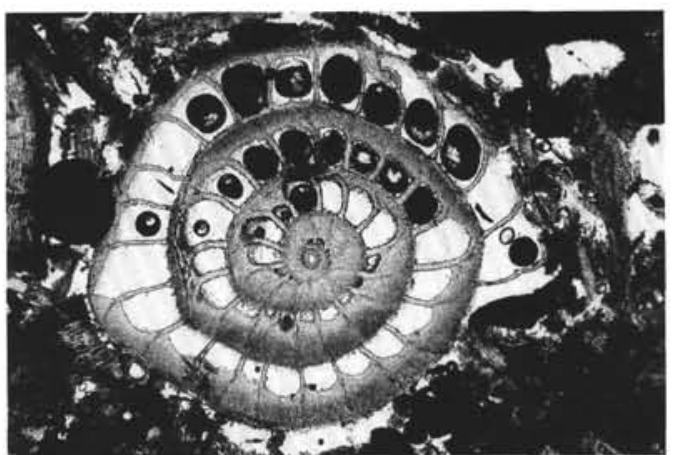

A

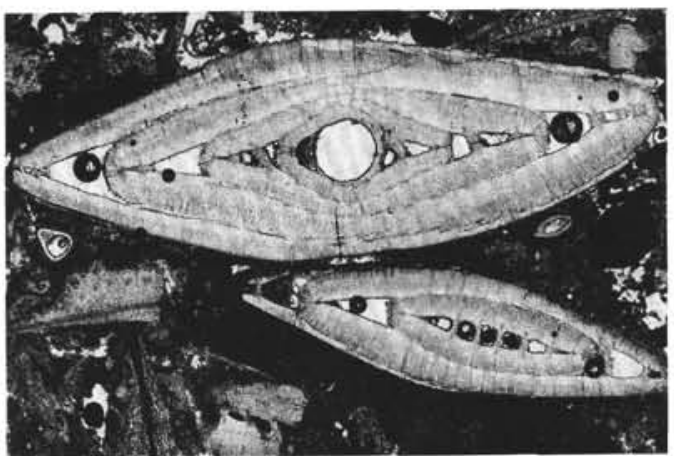

B

Figure 5. Sample 115-715A-18R-1, 20-22 cm. A. Nummulites partschi group, tangential section. Note the characteristically regular distribution of pillars $(\times 11)$. B. Nummulites burdigalensis group, equatorial, oblique and almost axial sections. Specimens with proloculus of the same size as $N$. b. cantabricus, but with more numerous septa per whorl $(\times 11)$.

cf. caupennensis. The occurrence of the aforementioned Nummulites characterizes the transition between the Nummulites burdigalensis cantabricus and Nummulites campesinus Zones, or the lower part of the $N$. campesinus Zone (Schaub, 1981).

Schaub (1981) considers the Nummulites campesinus Zone coeval with the Alveolina violae Zone of Hottinger (1960) and dates both zones as late Cuisian (i.e., late early Eocene). Schaub (1981) also suggests that those zones are coeval with the Discoaster sublodoensis nannofossil Zone, which should straddle the early to middle Eocene boundary according to Berggren et al. (1985) (see Fig. 3).

Among the planktonic foraminifers, especially from Core $115-715 \mathrm{~A}-12 \mathrm{R}$, the most age-diagnostic species is Planorotalites palmeri, the nominal species of the youngest zone belonging to the early Eocene according to Bolli (1957). Toumarkine (1983) and Toumarkine and Luterbacher (1985) reported that this taxon ranges from the upper part of Zone P8 through the lower part of Zone P9 (sensu Blow, 1969), which is equated to their Acarinina pentacamerata Zone (late early Eocene age).

The occurrence of Planorotalites palmeri in the upper part of the studied interval, slightly preceded by that of $N$. cf. caupennensis and $N$. pratti, along with the occurrence of specimens close to $N$. burdigalensis cantabricus and/or $N$. campesinus in the lower portion, help to pin down the age attribution of the sequence. According to Proto Decima (1980), P. palmeri was found in association with Discoaster sublodoensis, although it occurs much more frequently along with a nannofossil assemblage belonging to the underlying Discoaster lodoensis Zone. Schaub (1981) correlates the latter zone with the lower portion of the underlying Nummulites burdigalensis cantabricus and Alveolina dainellii Zones. The co-occurrence of the aforementioned transitional forms among the alveolinids and nummulitids with Planorotalites palmeri suggests that the interval studied could actually straddle the boundaries between the $A$. dainellii and $A$. violae Zones or the $N$. burdigalensis cantabricus and $N$. campesinus Zones. Based on this interpretation, we suggest that this sequence can be assigned to the late early Eocene (middle to late Cuisian).

\section{Hole 714A}

Hole 714A was drilled on the eastern shoulder of the Maldive Ridge at $05^{\circ} 03.6^{\prime} \mathrm{N}$ and $73^{\circ} 47.2^{\prime} \mathrm{E}$ in a water depth of $2038.3 \mathrm{~m}$ with a total penetration of $233.0 \mathrm{~m}$ (Backman, Duncan, et al., 1988). Hole 714A penetrated $19.55 \mathrm{~m}$ of late Pleistocene nannofossil ooze (Unit I); $100.45 \mathrm{~m}$ of middle to late Miocene nannofossil ooze down to 120.0 mbsf (Subunit IIA); and
$133 \mathrm{~m}$ of a lithology similar to Subunit IIA, but more lithified, down to 233.0 mbsf (Subunit II).

Three samples from calcareous pebbles of turbiditic origin included in Subunit II (Core 115-714A-24X-CC, 28-30 cm, 29$30 \mathrm{~cm}, 37-39 \mathrm{~cm}$ ) and assigned to the late Oligocene planktonic foraminifer Zone P22 (see Premoli Silva and Spezzaferri, this volume) are rich in reef-derived skeletal debris. Fossils in general are poorly preserved and mainly corroded at their edges. In Sample 115-714A-24X-CC, 29-30 cm, melobesian algae dominate and are associated with rare Amphistegina, Heterostegina, and fragments of molluscs (possibly ostreids). Rare planktonic foraminifers also occur, but their walls are micritized, thus preventing identification (Table 2).

In addition to melobesian algae, the other two samples contain numerous large benthic foraminifers that belong to the genera Nummulites ( $N$. fabianii group), Fabiania, Discocyclina, Alveolina, Operculina (O. gomezi), Heterostegina, and Amphistegina (Table 2). Although some of these genera can range as high as the late Oligocene, Discocyclina and Fabiania are typical of middle to late Eocene assemblages; O. gomezi and the representatives of the $N$. fabianii group (here recorded) are confined to the late Eocene. Thus, at least part of the shallow-water skeletal debris must be interpreted as reworked. The occurrence of the latter foraminifer genera and species suggests that a carbonate platform continued to grow in the vicinity of Site 714 in younger time (at least late Eocene) than at Hole 715A.

Table 2. Distribution of middle to late Eocene, shallow-water fossil content in Hole 714A.

\begin{tabular}{|c|c|c|c|c|c|c|c|c|c|c|c|c|c|c|}
\hline $\begin{array}{l}\text { Core, section, } \\
\text { interval }(\mathrm{cm})\end{array}$ &  & 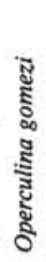 & $\begin{array}{l}\text { कि } \\
\text { जूँ } \\
\text { : }\end{array}$ & 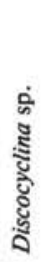 &  & 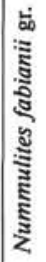 & 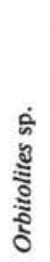 & 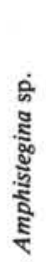 & 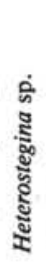 & 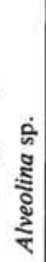 & 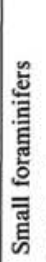 &  & है & $\begin{array}{l}\text { :ั0 } \\
\text { 돔 }\end{array}$ \\
\hline $\begin{array}{l}24 X-C C, \quad 28-30 \\
24 X-C C, 29-30 \\
24 X-C C, 37-39\end{array}$ & $\mathbf{P}$ & P & C & $\mathrm{P}$ & $\begin{array}{l}\mathrm{A} \\
\mathrm{P} \\
\mathrm{A}\end{array}$ & C & $P$ & $P$ & $\begin{array}{l}\mathrm{P} \\
\mathrm{P}\end{array}$ & C & $\begin{array}{l}\text { A } \\
\text { P } \\
\text { A }\end{array}$ & $\begin{array}{l}\mathrm{C} \\
\mathrm{A}\end{array}$ & $\mathbf{P}$ & $\mathbf{P}$ \\
\hline
\end{tabular}

Notes: Host sediments are attributed to late Oligocene Zone P22 (see Premoli Silva and Spezzaferri, this volume). $\mathrm{A}=$ abundant, $\mathrm{C}=\mathrm{com}$ mon, and $\mathrm{P}=$ present. 


\section{PALEOENVIRONMENTAL REMARKS AND CONCLUSIONS}

The succession of shallow-water facies recovered in Hole 715A indicates that by late early Eocene time a carbonate platform developed above the basement. Initially it was characterized by back-reef facies with abundant miliolids, rotaliids, agglutinated foraminifers, and Orbitolites, as well as sparse alveolinids and Nummulites in association with abundant melobesian algae. The carbonate platform then evolved toward a deeper, more open marine environment, as testified by the appearance of discocyclinids that become progressively more abundant upward along with frequent Nummulites (see Ferrer et al., 1973).

In the upper part of the sequence, the occurrence of well-diversified planktonic foraminifer faunas and the presence of strongly fragmented discocyclinids as well as some nummulitids oriented parallel to the bedding show that the carbonate platform stopped growing and sank below the euphotic zone. The time span between the initiation of the platform and its end appears to be very short, a few hundred thousand years only (Berggren et al., 1985). In Hole 715A the sedimentary sequence is truncated by a major hiatus that spans the latest early Eocene through middle Miocene and indicates that erosion predominated over deposition at Site 715 during this time.

At Hole 714A, the occurrence of shallow-water larger foraminifers of middle to late Eocene age, now enclosed in late Oligocene pelagic sediments, suggests that (1) in the Maldive Ridge area a carbonate platform, possibly spatially reduced in size in comparison with that of late early Eocene age, continued to grow later than early Eocene time (till at least the late Eocene); and (2) the presence of reef-derived skeletal debris in beds of turbiditic origin testifies to a major erosional event during the late Oligocene, as the pelagic sediments containing the turbiditic layers can be assigned to Zone P22 (Premoli Silva and Spezzaferri, this volume). This erosional event appears to be coeval with the youngest global sea-level fall of Oligocene age (Haq et al., 1988). Sea level during this event is estimated to be as much as $100 \mathrm{~m}$ lower than at present (Schlanger and Premoli Silva, 1986).

\section{ACKNOWLEDGMENTS}

The authors are indebted to ODP for having provided the samples for this study. Their warm thanks go to shipboard scientists A. Boersma, A. Droxler, D. Rio, and E. Vincent for the fruitful discussion about Leg 115 results. The authors would like to thank the technicians of the Department of Earth Sciences of Milan University, G. Chiodi for photographs, C. Malinverno for thin section preparation, and S. Antico for graphic arts. The authors are deeply indebted to R. Herb for his constructive critical review and the two anonymous reviewers whose remarks contributed to the improvement of this paper. Financial support for this research was provided by CNR-ESCO Program and by MPI ( $40 \%$ to IPS).

\section{SPECIES LIST}

The species identified are listed in alphabetic order. For the alveolinids and nummulitids, the classifications of Hottinger (1960) and Schaub (1981) have been followed. For the planktonic foraminifers, the generic and specific concepts by Premoli Silva and Boersma (1988) are retained whenever possible, with a few changes according to Toumarkine and Luterbacher (1985). References are made to figures of isolated specimens, even if this study was conducted on thin sections. In this case, identification was based in particular on the comparison of axial sections, whereas spiral views were taken into consideration for estimating the number of whorls and for determining how the size of chambers progressively increased in each species.

\section{Larger Foraminifers}

Alveolina aragonensis group Hottinger, 1960 (Plate 3, Fig. 1). See Hottinger (1960), Pl. 6, Figs. 5-10; Fig. 60 (b-f); Drobne (1977), Pl. 5, Figs. 1-6. Several specimens mainly not complete and poorly cut. The best specimen is a Form B that displays narrow and high chamberlets; a moderately, rather regularly increasing spire, with a thin basal thickening in the equatorial region and slightly more development at the poles; and a general shape that is a little more fusiform than the typical $A$. aragonensis. Diameter in the most complete specimens: $3 \mathrm{~mm}$; length/width ratio: 1.5 . Moreover, several other specimens exhibit transitional characters between this form and $A$. fornasinii, which in general should have a larger size.

Alveolina canavarii group Checchia-Rispoli, 1905 (Plate 2, Fig. 3; Plate 4, Fig. 1). See Hottinger (1960), Pl. 8, Figs. 15-18; Figs. 68 and 69. Small specimens, in unoriented cuts, with important basal thickening up to two-thirds of the spire height, more pronounced in the pole areas. Form more fusiform than $A$. canavarii. Length/width ratio: $1.8 \times 1 \mathrm{~mm}$.

Alveolina fornasinii Checchia-Rispoli, 1909 (Plate 1, Fig. 3). See Hottinger (1960), Pl. 6, Figs. 1-4; Fig. 60a. The illustrated specimen, not complete, has a proloculus of $0.45 \mathrm{~mm}$ and a length/width ratio: 2 , without basal thickening in the outer whorls at the poles. These characters are typical of $A$. fornasinii.

Alveolina sp. cf. A. dainellii Hottinger, 1960 (Plate 3, Fig. 5). See Hottinger (1960), Pl. 5, Figs. 12-14; Fig. 53. Common specimens, frequently not complete and not oriented. Diameter in the most complete specimens: $3.5-4 \mathrm{~mm}$. Chamberlets low and wide. Several specimens show basal thickening and coiling rate close to $A$. dainellii. Several other specimens possess higher chamberlets and show transitional characters between typical $A$. dainellii and $A$. palermitana (Plate 1, Figs. 4 and 6; Plate 2, Fig. 1).

Alveolina sp. aff. A. palermitana Hottinger, 1960 (Plate 2, Fig. 2; Plate 3, Fig. 3). See Hottinger (1960), Pl. 5, Figs. 17, 18; Fig. 54. Few specimens, poorly oriented. Some of them show very tight inner coils, followed by a few, much looser coils with important basal thickening (up to 10 times the height of the chamberlets) and outer whorls again rather tightly coiled. Although not centered, the described specimens are very close to $A$. aff. palermitana illustrated by Hottinger (1961, PI. 5, Fig. 16). Diameter of the most complete specimens: $3.5 \mathrm{~mm}$.

Discocyclina douvillei (Schlumberger, 1903) (= Orthophragmina douvillei Schlumberger). See Schweighauser (1953), Pl. 12, Fig. 3; Figs. 34 and 53.

Discocyclina sella (d'Archiac, 1850) (= Orbitolites sella d'Archiac) (Plate 2, Fig. 6; Plate 3, Fig. 6). See Schweighauser (1953), PI. 11, Figs. 2, 6, 10, 11, and 13; Figs. 22 and 49.

Fabiania sp. (Plate 5, Figs. 2 and 3).

Nummulites burdigalensis de la Harpe, 1926, emend. Schaub, 1951 (Plate 3, Fig. 8). See Schaub (1981), PI. 4, Figs. 10-12; Pl. 5, Figs. $1-18,27-31$, and $46-51$.

Nummulites burdigalensis group (Plate 3, Fig. 2). Specimens belonging to this group are common and show an acme between Samples 115$715 \mathrm{~A}-14 \mathrm{R}-1 \mathrm{R}-\mathrm{CC}$ and $115-715 \mathrm{~A}-13 \mathrm{R}-1,19-21 \mathrm{~cm}$. They are frequently badly oriented but exhibit the characteristic pillars, dimensions, and coiling rate typical of the group. Among those, in the lower part of the sequence, a few specimens display a large proloculus similar in size to that of $N$. burdigalensis cantabricus Schaub, 1981, but with a number of septa greater than the typical $N$. b. cantabricus. A Form B specimen (Plate 3, Fig. 2) exhibits sizes $(8.5 \times 5 \mathrm{~mm}$ ), numbers of coils, and distribution of pillars on the surface, recording characters in between $N . b$. cantabricus and $N$. campesinus (see below).

Nummulites campesinus Schaub, 1966. See Schaub (1981), PI. 7, Figs. 23-44; Pl. 8, Figs. 1-22; Pl. 9, Figs. 1-20.

Nummulites sp. cf. N. caupennensis Schaub, 1962 (Plate 2, Fig. 5; Fig. 4A). See Schaub (1981), Pl. 45, Figs. 1-19, 22-25. In the specimen of Fig. 4A, septa are at a right angle at the base and recurved at the top; on the third whorl septa show the characteristic sharp inflection of $N$. caupennensis. Chambers higher than wider, 7 per sector, marginal cord well developed. Size of proloculus $(0.35 \mathrm{~mm})$ as in $N$. caupennensis. The specimen (Form B) in Plate 2, Figure 5, in slightly oblique axial section, is here referred to $N$. caupennensis because of the characteristically irregular shape of the outer whorls (see Schaub, 
1981, Pl. 45, Fig. 22). Associated to the forms described above, there are also several specimens, in poorly oriented cuts, that show slightly flexuous septal filaments, gently thickened to form few small pillars. Because of the sizes, they may be related to $N$. caupennensis, but they possess septal filaments similar to $N$. formosus de la Harpe, 1883.

Nummulites fabianii group Prever, 1905 (Plate 5, Fig. 1). See Schaub (1981), Pl. 49, Figs. 57-69; Pl. 50, Figs. 1-4. Few oblique sections characteristic of the $N$. fabianii group.

Nummulites partschi group de la Harpe, 1880 (Fig. 5A). See Schaub (1981), Pl. 28, Figs. 1-20; Pl. 29, Figs. 1-14; Fig. 80. Some specimens, tangentially cut, exhibit a regular distribution of pillars characteristic of the $N$. partschi group.

Nummulites pratti d'Archiac and Haime, 1853 (Plate 3, Fig. 6; Fig. 4B). See Schaub (1981), PI. 65, Figs. 32-53. We attributed several specimens to this species that displayed a large proloculus $(0.5 \mathrm{~mm})$ and a growth rate similar to that of $N$. pratti. The specimen illustrated in Plate 3, Figure 6, is a characteristic axial section of $N$. pratti Form B.

Operculina gomezi Colom and Bauzà, $1950(=$ Operculina canalifera d'Archiac subsp. gomezi Colom and Bauzà) (Plate 5, Fig. 1). See Ellis and Messina (1940); Hottinger (1977), Figs. 38 (A-F).

Orbitolites sp. cf. Orbitolites douvillei (Nuttall, 1925) (= Opertorbitolites douvillei Nuttall) (Plate 1, Fig. 1). See Lehmann (1961), Pl. 7, Figs. 1-10; Figs. 27 and 28.

\section{Planktonic Foraminifers}

"Acarinina" aquiensis (Loeblich and Tappan, 1957) (= Globigerina aquiensis Loeblich and Tappan). See Loeblich and Tappan (1957), Pl. 56, Figs. 4a-6c.

Acarinina gravelli (Brönnimann, 1952) (= Globigerina gravelli Brönnimann). See Brönnimann (1952), Pl. 1, Figs. 16-18.

Acarinina pentacamerata Subbotina, 1953. See Subbotina (1953), Pl. XXIV, Figs. 1-6.

Acarinina pseudotopilensis Subbotina, 1953 (Plate 5, Fig. 6). See Subbotina (1953), Pl. XXI, Figs. 8 and 9; PI. XXII, Figs. 1 and 2.

"Globigerinatheka" senni (Beckmann, 1953) (= Sphaeroidinella senni Beckmann) (Plate 5, Fig. 8). See Toumarkine (1978), Pl. 10, Figs. $10-14$.

Morozovella aragonensis (Nuttall, 1930) $(=$ Globorotalia aragonensis Nuttall) (Plate 5, Fig. 4). See Blow (1979), Pl. 141, Figs. 4-9.

"Morozovella" convexa (Subbotina, 1953) (= Globorotalia convexa Subbotina). See Subbotina (1953), Pl. XVII, Figs. 2 and 3.

Morozovella crassata (Cushman, 1925) (= Pulvinulina crassata Cushman). See Toumarkine and Luterbacher (1985), Fig. 30 (9-10).

Morozovella spinulosa (Cushman, 1927) (= Globorotalia spinulosa Cushman). See Toumarkine and Luterbacher (1985), Fig. 30 (1 and 2).

Planorotalites palmeri (Cushman and Bermudez, 1937) $(=$ Globorotalia palmerae Cushman and Bermudez). (Plate 4, Fig. 9; Plate 5, Fig. 5). See Toumarkine and Luterbacher (1985), Fig. 20 (14-29).

Planorotalites pseudoscitulus (Glaessner, 1937) (= Globorotalia pseudoscitula Glaessner) (Plate 4, Fig. 6). See Blow (1979), Pl. 173, Figs. 1-8.

Pseudohastigerina wilcoxensis (Cushman and Ponton, 1932) (= Nonion wilcoxensis Cushman and Ponton) (Plate 5, Fig. 13). See Berggren et al. (1967), Fig. 2.

Subbotina pseudoeocaena (Subbotina, 1953) $(=$ Globigerina pseudoeocaena Subbotina) (Plate 5, Fig. 15). See Subbotina (1953), Pl. V, Figs. 1 and 2.

"Turborotalia" praecentralis (Blow, 1979) $(=$ Globorotalia praecentralis Blow). (Plate 5, Fig. 12). See Blow (1979), Pl. 135, Figs. 7-9; Pl. 136, Figs. 1-6.

\section{REFERENCES}

Backman, J., Duncan, R. A., et al., 1988. Proc. ODP, Init. Repts., 115: College Station, TX (Ocean Drilling Program).

Berggren, W. A., Kent, D. V., and Flynn, J. J., 1985. Jurassic to Paleogene: Part 2, Paleogene geochronology and chronostratigraphy. In Snelling, N. J. (Ed.), The Chronology of the Geological Record. Geol. Soc. Mem. (London), 10:141-195.

Berggren, W. A., Olsson, R. K., and Reyment, R. A., 1967. Origin and development of the foraminiferal genus Pseudohastigerina Banner and Blow. Micropaleontology, 13:265-288.
Blow, W. H., 1969. Late middle Eocene to Recent planktonic foraminiferal biostratigraphy. In Brönnimann, P., and Renz, H. H. (Eds.), Proceedings of the First International Conference on Planktonic Microfossils, Geneva: Leiden (E. J. Brill), 199-422. , 1979. The Cenozoic Globigerinida: Leiden (E. J. Brill).

Bolli, H. M., 1957. Planktonic foraminifera from the Eocene Navet and San Fernando formations of Trinidad, B.W.I. Bull. U.S. Nat. Mus., 215:155-172.

Brönnimann, P., 1952. Trinidad Paleocene and Lower Eocene Globigerinidae. Bull. Am. Paleontol., 34:1-34.

Drobne, K., 1977. Alvéolines paléogènes de la Slovénie et de l'Istrie. Schweiz. Palaeontol. Abh., 99.

Ellis, B. F., and Messina, A. R., 1940 et seq. Catalogue of Foraminifera: New York (American Museum of Natural History).

Ferrer, J., Le Calvez, Y., Luterbacher, H. P., and Premoli Silva, I., 1973. Contribution à l'étude des foraminifères ilerdiens de la région de Tremp (Catalogne). Mem. Mus. Nat. Hist. Nat., Ser. C (Paris), 29:1-107.

Haq, B. U., Hardenbol, J., and Vail, P. R., 1988. Mesozoic and Cenozoic chronostratigraphy and cycles of sea-level change. In Wilgus, C., et al. (Eds.), Sea-Level Change-An Integrated Approach. Spec. Publ., Soc. Econ. Paleontol. Mineral., 42:71-108.

Hottinger, L., 1960. Recherches sur les Alvéolines du Paléocène et de l'Eocène. Schweiz. Palaeontol. Abh., 75/76.

1977. Foraminifères operculiniformes. Mem. Mus. Nat. Hist. Nat., Ser. C. (Paris), 40: 1-159.

Hottinger, L., and Schaub, H., 1960. Zur Stufeneinteilung des Paleocaens und des Eocaens: Einfuhrung der Stufen Ilerdien und Biarritzien. Eclogae Geol. Helv., 53:453-480.

Lehmann, R., 1961. Strukturanalyse einiger Gattung der Subfamilie Orbitolitinae. Eclogae Geol. Helv., 54:597-667.

Loeblich, A. R., Jr., and Tappan, H., 1957. Planktonic foraminifera of Paleocene and early Eocene age from the Gulf and Atlantic coastal plains. Bull. U.S. Nat. Mus., 215:173-198.

Premoli Silva, I., and Boersma, A., 1988. Atlantic Eocene planktonic foraminiferal historical biogeography and paleohydrographic indices. Palaeogeogr., Palaeoclimatol., Palaeoecol., 67:315-356.

Proto Decima, F., 1980. Distribuzione mondiale di Globorotalia palmerae Cushman and Bermudez e correlazione con la stratigrafia basata sul nannoplancton calcareo. Paleontol. Stratigr. Evol., 1:163-164.

Schaub, H., 1981. Nummulites et Assilines de la Téthys paléogène: taxinomie, phylogenèse et biostratigraphie. Schweiz. Palaeontol. Abh., 104/105/106.

Schlanger, S. O., and Premoli Silva, I., 1986. Oligocene sea-level fall recorded in mid-Pacific atoll and archipelagic apron settings. Geology, 14:392-395

Schweighauser, J., 1953. Mikropalaeontologische und stratigraphische Untersuchungen im Paleocaen und Eocaen des Vicentin (Norditalien). Schweiz. Palaeontol. Abh., 70:1-97.

Subbotina, N. N., 1953. Fossil foraminifers of the USSR: Globigerinidae, Hantkeninidae, Globorotaliidae. Tr. Vost. Nauchno-Issled. Gornorudn. Inst., n.s., 76:1-296 (in Russian).

Toumarkine, M., 1978. Planktonic foraminiferal biostratigraphy of the Paleogene of Sites 360 to 364 and the Neogene of Sites 362A, 363, and 364 Leg 40. In Bolli, H. M., Ryan, W.B.F., et al., Init. Repts. DSDP, 40: Washington (U.S. Govt. Printing Office), 679-738.

1983. Les foraminifères planctoniques de 1'Eocène moyen et supérieur des régions tropicales à temperées chaudes ( $\mathrm{Ph} . \mathrm{D}$. dissert.). Univ. Paris VI.

Toumarkine, M., and Luterbacher, H. P., 1985. Paleocene and Eocene planktic foraminifera. In Bolli, H. M., Saunders, J. B., and PerchNielsen, K. (Eds.), Plankton Stratigraphy: Cambridge (Cambridge Univ. Press), 87-154.

Whitmarsh, R. B., Weser, O. E., Ross, D. A., et al., 1974. Init. Repts. $D S D P$, 23: Washington (U.S. Govt. Printing Office).

Date of initial receipt: 30 May 1989

Date of acceptance: 6 December 1989

Ms 115B-148 



3



5

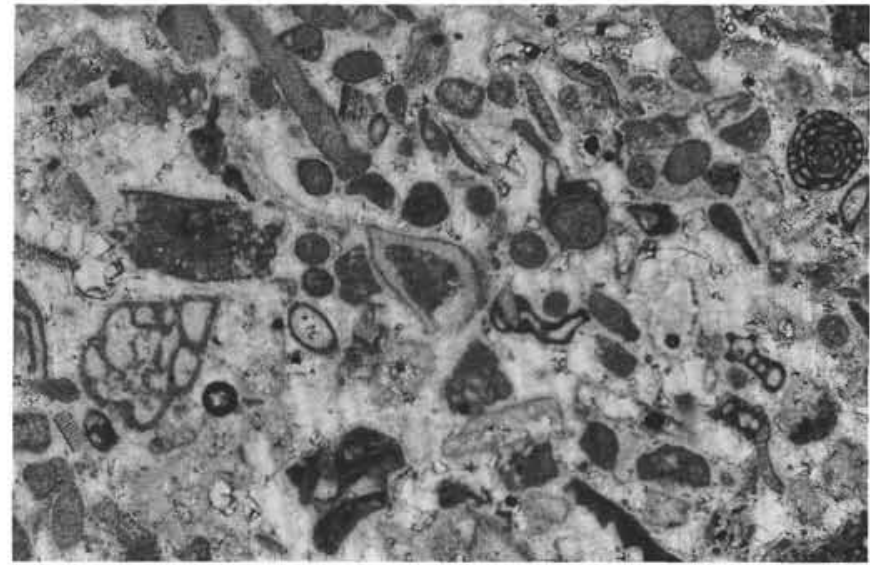

2

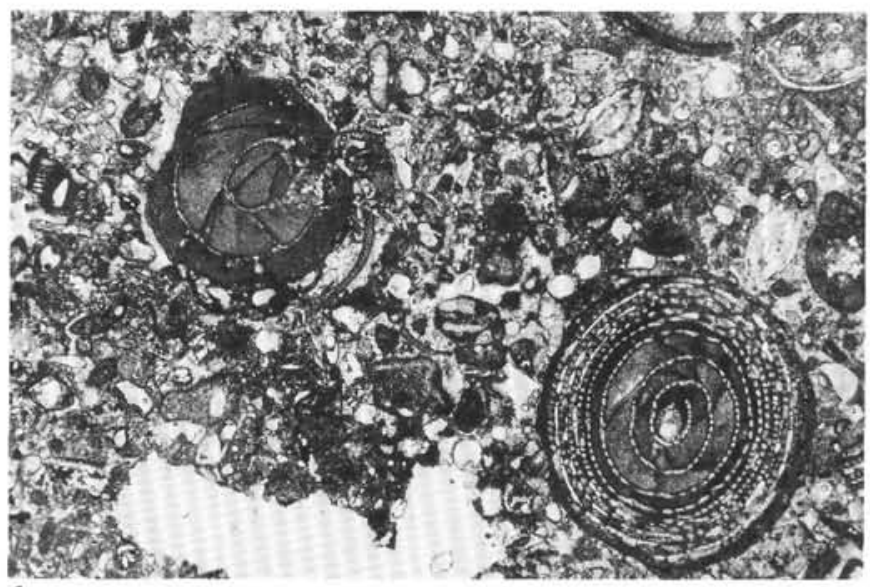
4

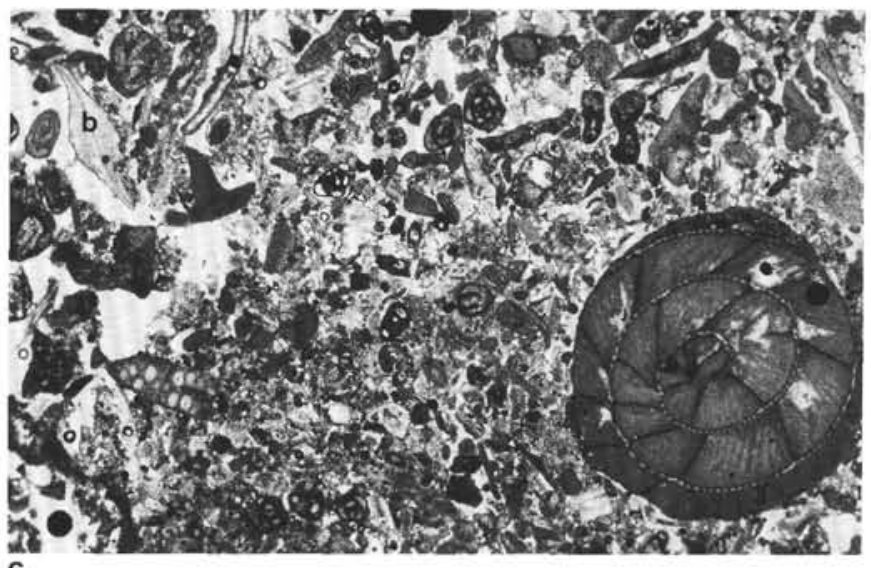

6

Plate 1. 1. Bioclastic packstone with abundant small foraminifers. (a) Orbitolites cf. douvillei. (b) Oblique section of Orbitolites sp. (c) Alveolina sp. possibly related to the $A$. aragonensis group, oblique axial section. (d) Alveolina sp.; Sample 115-715A-23R-1, 34-36 cm ( $\times 7.5$ ). 2. Bioclastic grainstone with abundant small foraminifers, fragments of melobesian algae, and Alveolina sp. (inner whorls); Sample 115-715A-22R-CC ( $\times 9$ ). 3. Bioclastic packstone with abundant small foraminifers. (a) Alveolina sp., oblique sections. (b) Alveolina fornasinii, axial section. (c) Nummulites sp.; Sample 115-715A-21R-1, 27-28 cm $(\times 6.5)$. 4. Bioclastic packstone with abundant small foraminifers, small Nummulites sp., and Alveolina dainellii/A. palermitana transitional forms, oblique sections; Sample 115-715A-19R-1, 22-24 cm ( $\times 7.5)$. 5. Bioclastic packstone with abundant small foraminifers. (a) Alveolina sp. possibly related to A. fornasinii, axial section. (b) Alveolina sp., oblique section. (c) Discocyclinid. (d) Encrusting algae; Sample 115-715A-19R-1, 2-5 cm $(\times 11)$. 6. Bioclastic packstone with abundant small foraminifers. (a) Alveolina sp. possibly related to A. dainellii/A. palermitana. (b) Discocyclina sp.; Sample 115-715A-17R-CC $(\times 7.5)$. 

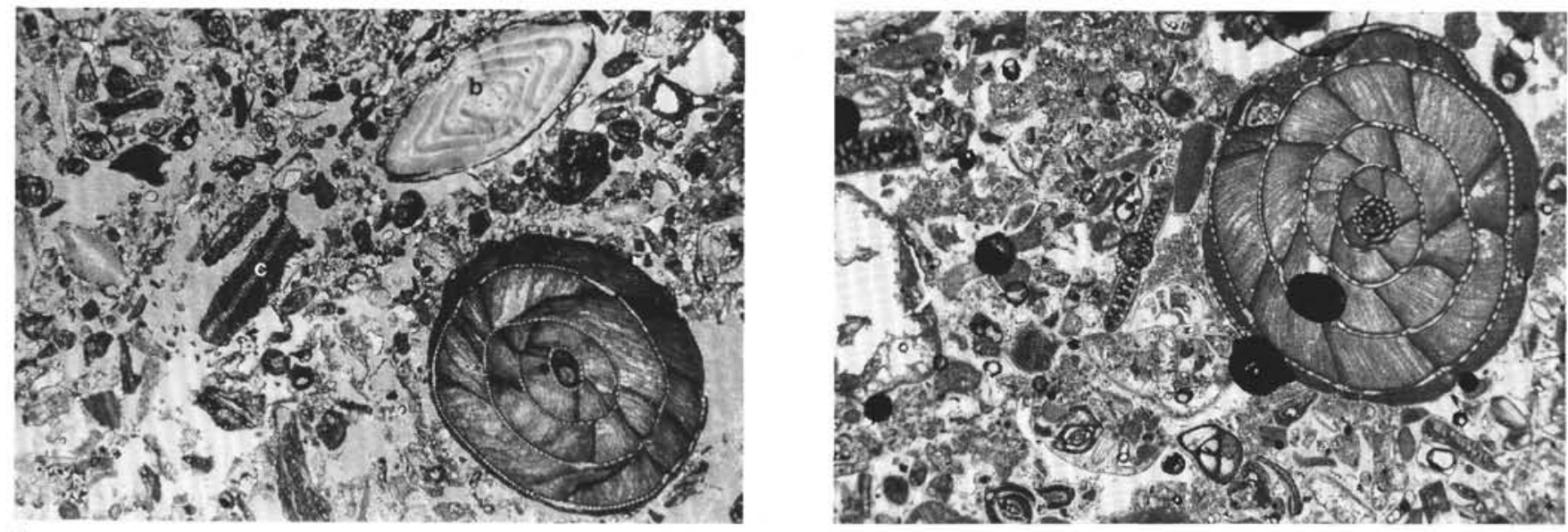

1

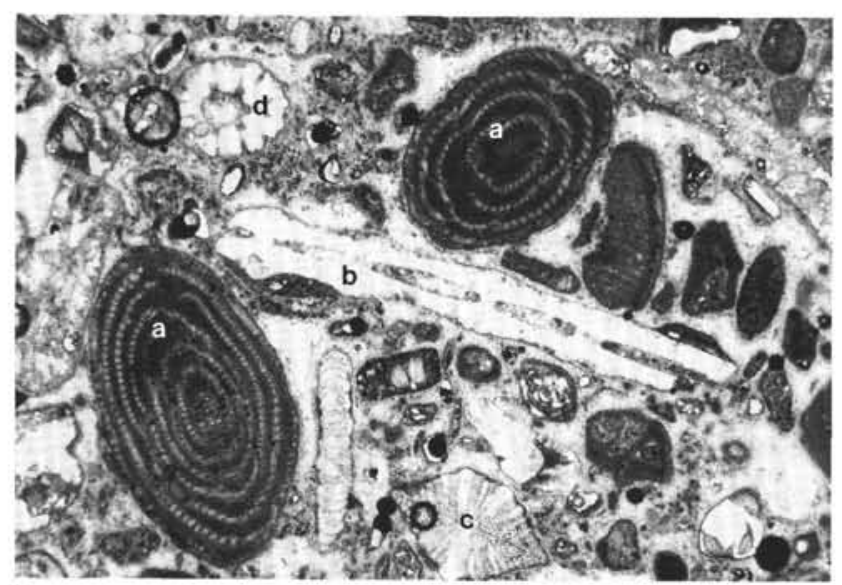

2
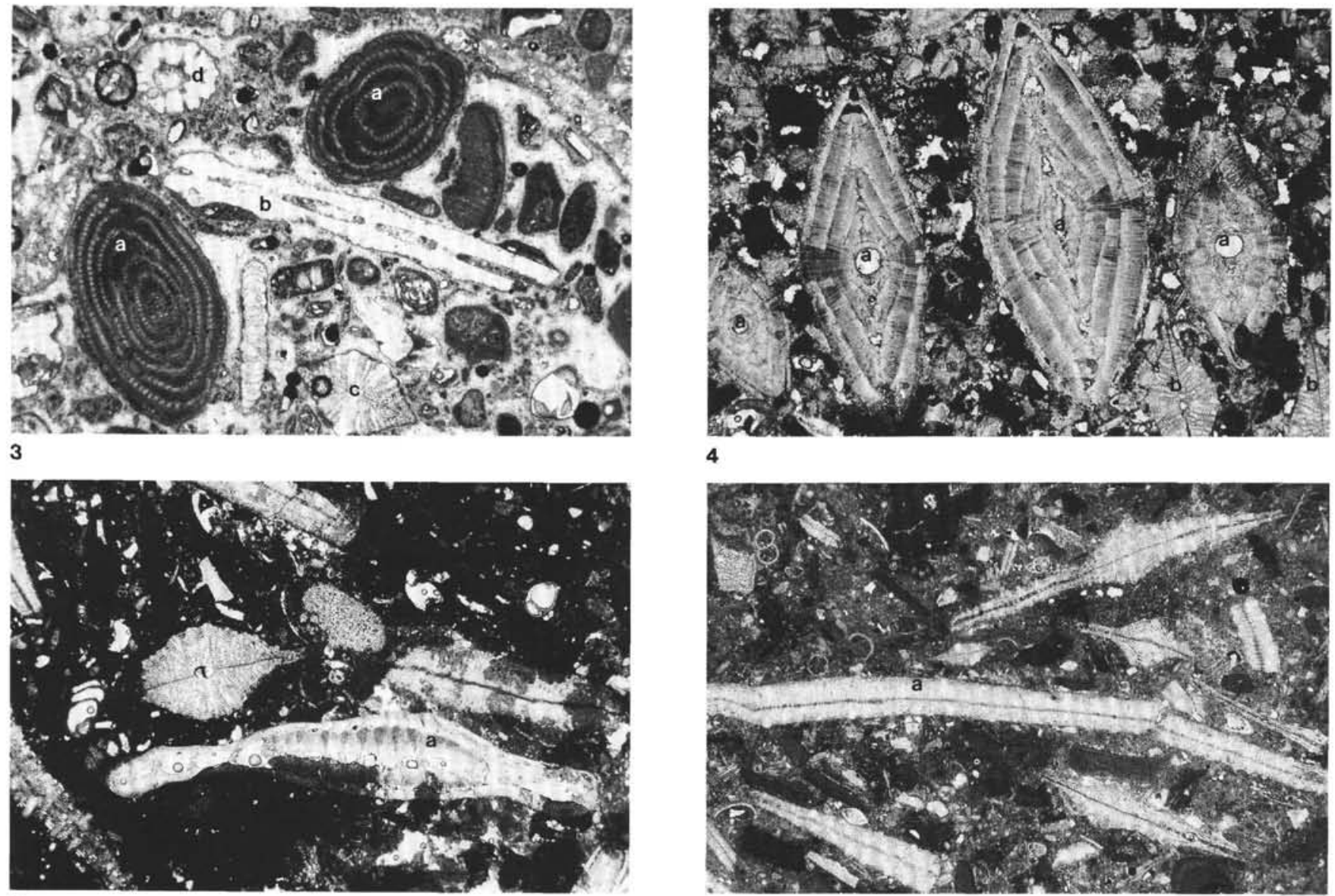

Plate 2. 1. Bioclastic packstone/grainstone with abundant small foraminifers. (a) Alveolina dainellii/A. palermitana transitional forms, oblique section. (b) Nummulites sp. (c) Fragments of Orbitolites sp.; Sample 115-715A-16R-1, 18-20 cm ( $\times 7.5)$. 2. Bioclastic packstone with abundant small foraminifers and fragments of Orbitolites sp. (a) Alveolina sp. related to A. aff. palermitana; Sample 115-715A-16R-1, 2-5 cm ( $\times 11)$. 3. Bioclastic packstone. (a) Alveolina sp. probably related to A. canavarii group, axial and oblique sections. (b) Operculina sp. (c) Discocyclina sp. (d) Dasycladacean alga associated with small foraminifers; Sample 115-715A-14R-CC $(\times 16.5)$. 4. Bioclastic packstone. (a) Nummulites sp. (b) Discocyclinids oriented parallel to the bedding plane, associated with abundant, strongly fragmented discocyclinids; Sample 115-715A-13R-1, 19-21 cm $(\times 12)$. 5. Bioclastic wackestone. (a) Nummulites $\mathrm{cf}$. caupennensis associated with discocyclinids. Note rare planktonic foraminifers in the background; Sample 115-715A-13R-1, 8-10 cm (×11). 6. Bioclastic packstone. (a) Discocyclina sella and other discocyclinids, fragments of melobesian algae, and some planktonic foraminifers; Sample 115-715A-12R-CC, 18-21 cm $(\times 12)$. 


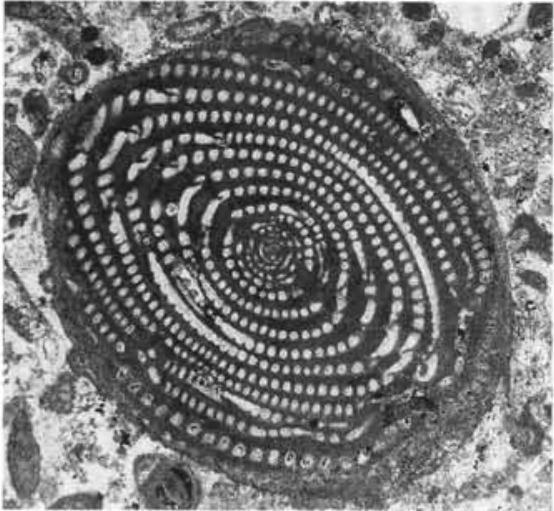

1

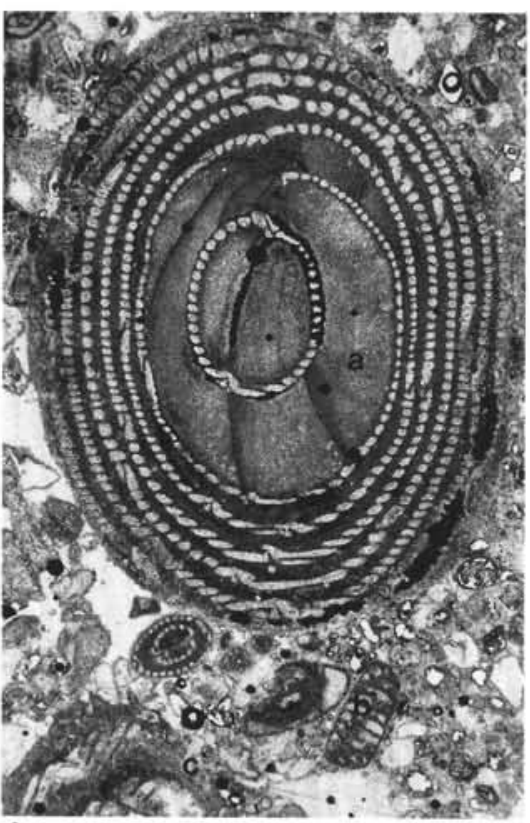

4

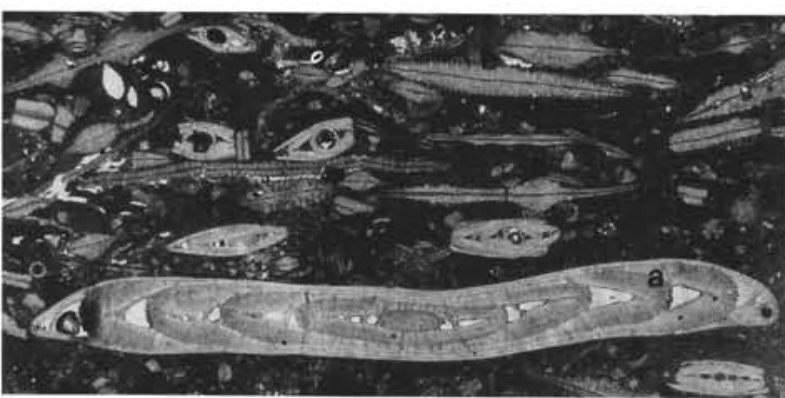

6



2


5

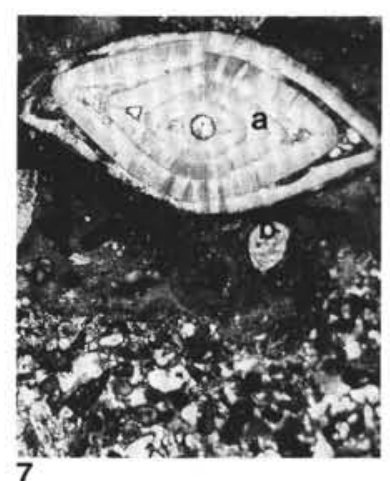

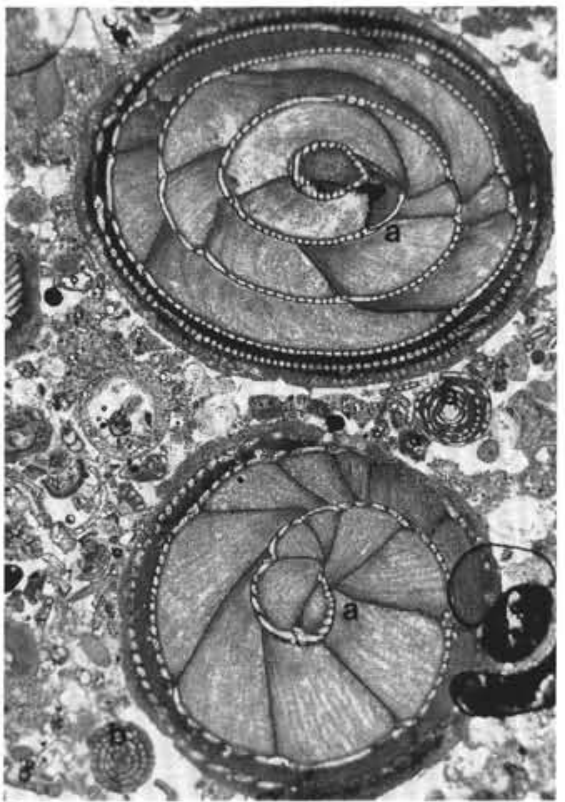

3



8

Plate 3. 1. Alveolina aragonensis group, Form B, axial section; Sample $115-715 \mathrm{~A}-21 \mathrm{R}-1,8-10 \mathrm{~cm}(\times 18)$. 2. Nummulites burdigalensis cantabricus/N. campesinus transitional form, Form B, axial section; Sample 115-715A-21R-1, 8-10 cm $(\times 8)$. 3. Bioclastic packstone with abundant small foraminifers. (a) Alveolina aff. palermitana, oblique sections. (b) Inner whorls of Alveolina sp.; Sample 115-715A-20R-CC ( $\times 12)$. 4. Bioclastic packstone with abundant small foraminifers. (a) Alveolina sp., oblique axial section. (b) Fragment of Orbitolites sp. (c) Discocyclinid; Sample 115$715 \mathrm{~A}-14 \mathrm{R}-1,40-43 \mathrm{~cm}(\times 15)$. 5. Alveolina sp. possibly related to A. dainellii; Sample $115-715 \mathrm{~A}-16 \mathrm{R}-1,2-5 \mathrm{~cm}(\times 15)$. 6. Bioclastic packstone/ wackestone. (a) Nummulites pratti, Form B, axial section, and several fragmented specimens of Nummulites, Forms A and B. (b) Discocyclina sella. (c) Asterocyclina sp. and several other discocyclinids, associated with planktonic foraminifers; Sample 115-715A-12R-1, 44-46 cm ( $\times 10)$. 7. Bioclastic packstone. (a) Nummulites sp., Form A, axial section. (b) Rotaliid, associated with discocyclinids and small foraminifers; Sample 115-715A$18 \mathrm{R}-1,19-20 \mathrm{~cm}(\times 18)$. 8. Bioclastic packstone with abundant small foraminifers. (a) Nummulites burdigalensis, discocyclinids, and fragments of alveolinids; Sample 115-715A-14R-1, 44-45 cm ( $\times 12)$. 


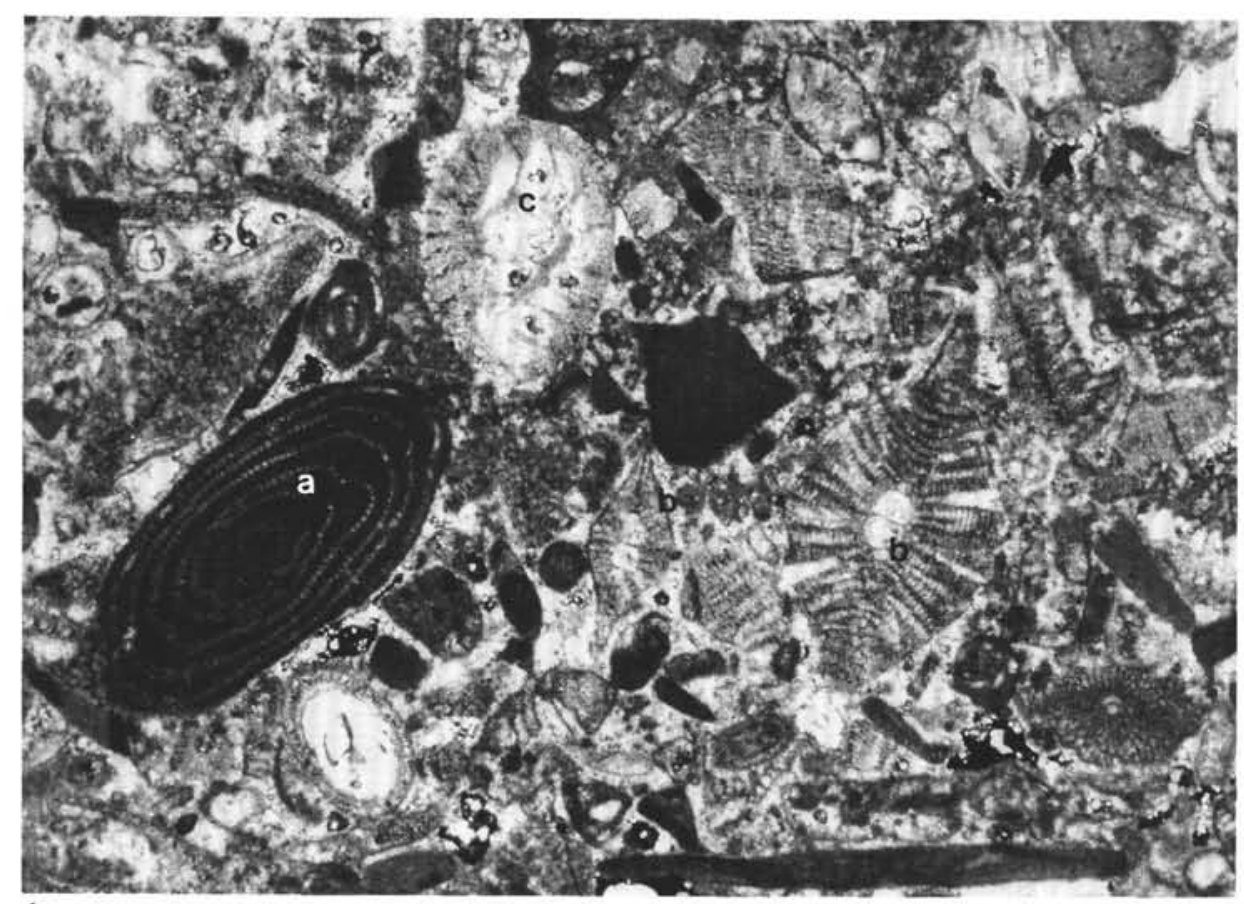

1

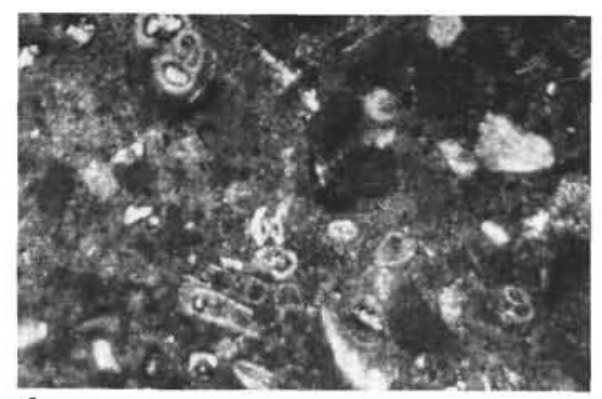

4



5



6

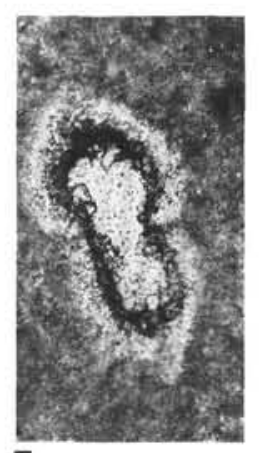

7

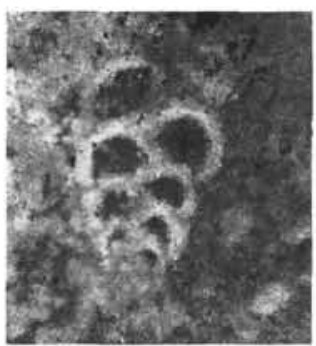

8

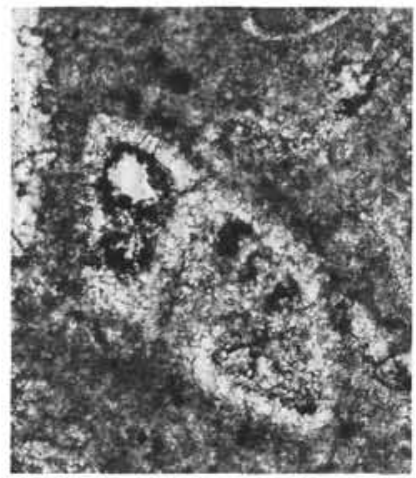

2



3



9

Plate 4. 1. Bioclastic packstone with abundant small foraminifers. (a) Alveolina sp., possibly A. canavarii group, oblique axial section. (b) Discocyclinids. (c) Nummulites sp.; Sample 115-715A-13R-1, 10-11 cm (×12). 2. Planorotalites pseudoscitulus; Sample 115-715A-12R-1, 18-21 cm $(\times 330)$. 3. Morozovella sp.; Sample 115-715A-12R-CC, $97-99 \mathrm{~cm}(\times 60)$. 4. Bioclastic wackestone/packstone with common planktonic foraminifers; Sample 115-715A-12R-1, 44-46 cm ( $\times 5)$. 5. Bioclastic wackestone/packstone with common planktonic foraminifers, discocyclinids, and melobesian algae; Sample 115-715A-12R-1, 44-46 cm $(\times 5)$. 6. Planorotalites pseudoscitulus; Sample 115-715A-12R-1, 44-46 cm $(\times 300) . \quad 7$. Pseudohastigerina sp.; Sample 115-715A-12R-1, 44-46 cm ( $\times 300)$. 8. Chiloguembelina sp.; Sample 115-715A-12R-1, 44-46 cm $(\times 115)$. 9. Planorotalites palmeri; Sample 115-715A-12R-1, 44-46 cm $(\times 300)$. 


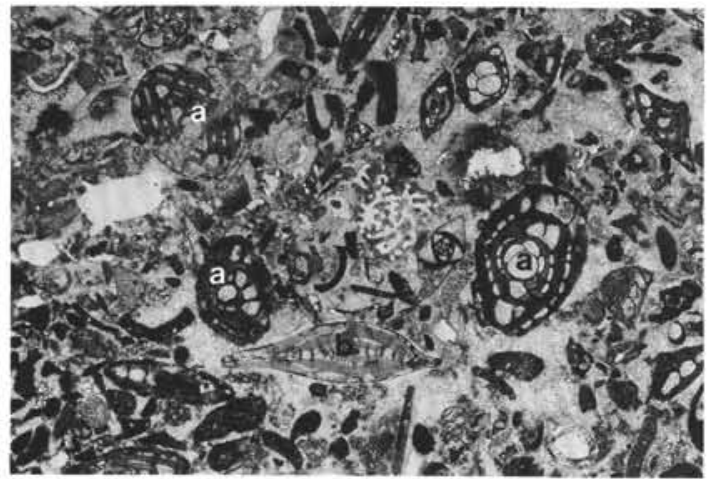

1

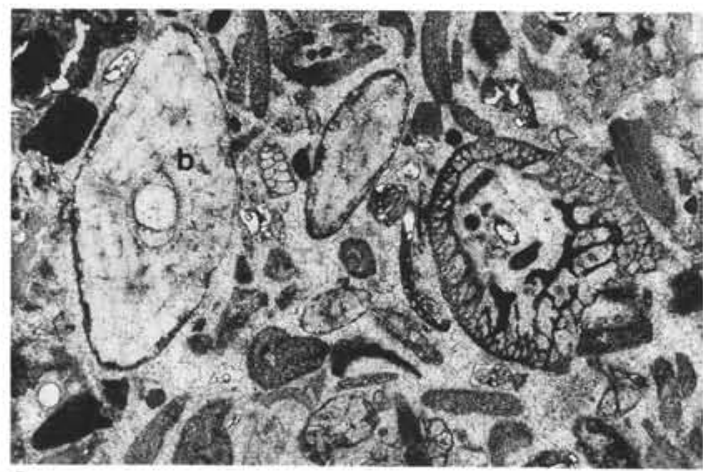

3

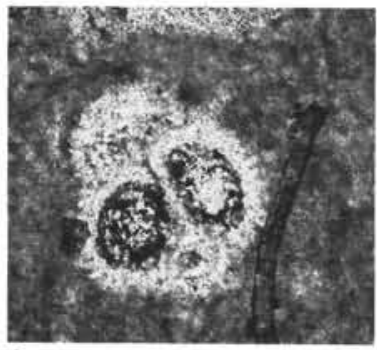

8

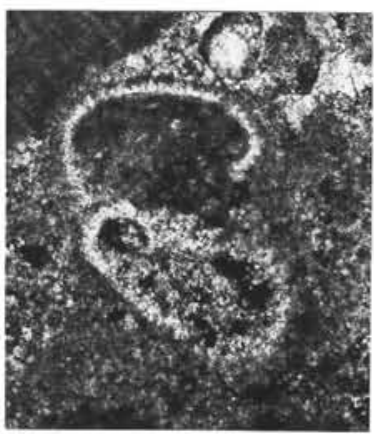

12



9

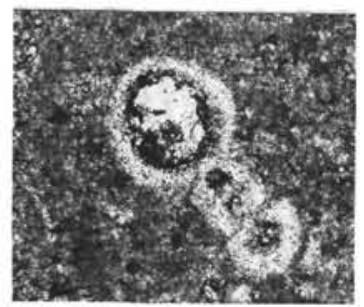

13
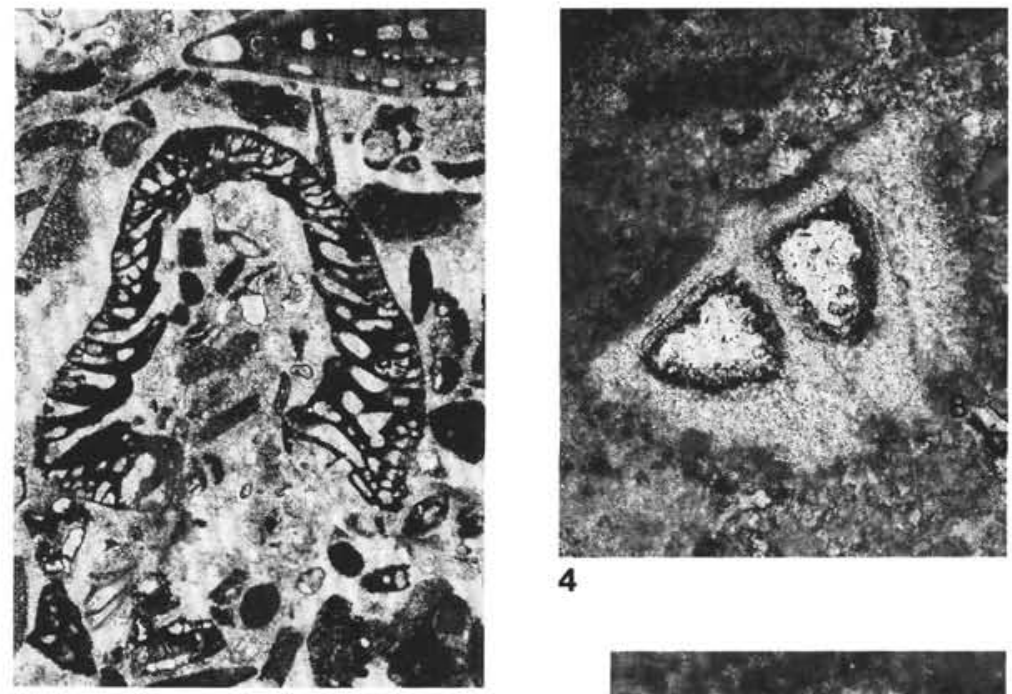

4



7



15

Plate 5. 1. Bioclastic grainstone. (a) Different cuts of Nummulites fabianii group. (b) Operculina gomezi, axial section, and small foraminifers; Sample 115-714A-24X-CC, 37-39 cm ( $\times 12.5)$. 2. Bioclastic grainstone. (a) Fabiania sp. (b) Nummulites sp.; Sample 115-714A-24X-CC, 37-39 cm ( $\times 20)$. 3. Bioclastic grainstone. (a) Fabiania sp. (b) Nummulites sp. and small foraminifers; Sample 115-714A-24X-CC, 28-30 cm $(\times 12.5)$. 4. Morozovella $\mathrm{cf}$. aragonensis; Sample 115-715A-12R-CC, $18-21 \mathrm{~cm}(\times 80)$. 5. Planorotalites $\mathrm{cf}$. palmeri; Sample 115-715A-12R-1, 44-46 cm $(\times 125)$. 6. Acarinina pseudotopilensis; Sample 115-715A-12R-CC, $18-21 \mathrm{~cm}(\times 115)$. 7. Morozovella? sp.; Sample $115-715 \mathrm{~A}-12 \mathrm{R}-\mathrm{CC}, 97-99 \mathrm{~cm}(\times 105)$. 8. "Globigerinatheka" senni; Sample 115-715A-12R-1, 44-46 cm ( $\times 145)$. 9. Planorotalites sp.; Sample $115-715 \mathrm{~A}-12 \mathrm{R}-\mathrm{CC}, 18-21 \mathrm{~cm}(\times 125)$. 10. Planorotalites sp.; Sample $115-715 \mathrm{~A}-12 \mathrm{R}-1,44-46 \mathrm{~cm}(\times 165)$. 11. Acarinina sp.; Sample 115-715A-12R-1, $44-46 \mathrm{~cm}(\times 95)$. 12. "Turborotalia" cf. praecentralis; Sample 115-715A-12R-CC, $18-21 \mathrm{~cm}(\times 105)$. 13. Pseudohastigerina wilcoxensis; Sample $115-715 \mathrm{~A}-12 \mathrm{R}-\mathrm{CC}, 18-21 \mathrm{~cm}(\times 105)$. 14. Acarinina sp.; Sample $115-715 \mathrm{~A}-12 \mathrm{R}-\mathrm{CC}, 18-21 \mathrm{~cm}(\times 110)$. 15. Subbotina $\mathrm{cf}$. pseudoeocaena; Sample $115-715 \mathrm{~A}-12 \mathrm{R}-1,44-46 \mathrm{~cm}(\times 115)$. 